\title{
Analysis of chromosomal and genetic disorders in patients with recurrent miscarriages in Saudi Arabia
}

Rola F. Turki ${ }^{1}$, Huda A. Banni ${ }^{2}$, Mourad Assidi ${ }^{2,3}$, Mohammed H. Al-Qahtani ${ }^{2}$, Hassan S. Abduljabbar ${ }^{1}$, Hassan S. Jamel ${ }^{1}$, Abdulrahim A. Rouzi ${ }^{1}$, Adel M. Abuzenadah ${ }^{2,3^{*}}$

From 2nd International Genomic Medical Conference (IGMC 2013)

Jeddah, Kingdom of Saudi Arabia. 24-27 November 2013

\section{Background}

Recurrent spontaneous abortion has been reported to occur in $15-20 \%$ of all clinically recognizable pregnancies. Numerous studies have reported a clear relationship between the chromosomal abnormalities in parents and recurrent miscarriages and infertility [1-3], however limited data is available from Arabian Peninsula. The main goal of this study was to determine the prevalence of chromosomal abnormalities and correlate them with clinical characteristics of couples with recurrent spontaneous abortions (RSA) in Saudi Arabia.

\section{Materials and methods}

Cytogenetic analysis of 171 consent patients with spontaneous recurrent abortions was performed by the standard method of 72-hour lymphocyte culture and GTG banding.

Table 1 Clinical features of RSA patients with chromosomal abnormalities in RSA cases

\begin{tabular}{|c|c|c|c|}
\hline & Normal karyotypes & Chromosomal abnormalities & $P$ value ${ }^{*}$ \\
\hline \multicolumn{4}{|l|}{ Patient gender } \\
\hline Male & 70 & 3 & 0.356 \\
\hline Female & 90 & 8 & \\
\hline \multicolumn{4}{|l|}{ Abortion stage } \\
\hline Trimester 1 & 68 & 10 & 0.452 \\
\hline Trimester 2 or 3 & 19 & 01 & \\
\hline \multicolumn{4}{|l|}{ Abortion frequency } \\
\hline$\leq 3$ & 49 & 4 & 0.339 \\
\hline$>3$ & 40 & 7 & \\
\hline \multicolumn{4}{|l|}{ Type of marriage } \\
\hline Consanguineous & 51 & 7 & 0.046 \\
\hline Non-consanguineous & 109 & 4 & \\
\hline \multicolumn{4}{|l|}{ Citizenship } \\
\hline Saudi & 117 & 6 & 0.295 \\
\hline Non Saudi & 43 & 5 & \\
\hline
\end{tabular}

*Fisher exact test (significance value, $P<0.05$ )

\footnotetext{
* Correspondence: adel_abuzenadah@hotmail.com

${ }^{2}$ Center of Excellence in Genomic Medicine Research, King Abdulaziz

University, Jeddah, Kingdom of Saudi Arabia

Full list of author information is available at the end of the article
}

\section{Ciomed Central}


Further validation by conventional PCR and gel electrophoresis was done whenever required.

\section{Results}

Our results showed that $6.43 \%$ of patients are carrier of a chromosomal abnormality. The prevalence of mosaicism, balanced translocations, duplications, Robertson translocation, triple $\mathrm{X}$ syndrome, and allelic polymorphism were $2.34 \%, 1.17 \%, 1.17 \%, 0.58 \%, 0.58 \%$ and $1.17 \%$ respectively. Interestingly, our data showed that women exhibited a higher prevalence to these chromosomal and genetic aberrations than men with female to male ratio of 2.7:1. A significant correlation $(P<0.05$; Table 1$)$ was found between consanguineous marrying families and chromosomal abnormalities in subjects with recurrent abortions, confirming previous findings [4,5]. Surprisingly, $78.6 \%$ of young women ( $\leq 35$ years) with chromosomal aberrations had recurrent miscarriages and therefore infertility problems.

\section{Conclusions}

The current study reported a strong association between the higher rates of chromosomal abnormalities and recurrent spontaneous abortions. Given the high rate of consanguineous marriages in the Saudi population, these results underline the importance of systematic cytogenetic investigation and genetic counseling preferably at the premarital stage or at least during early pregnancy phase (Preimplantation genetic diagnosis) as recommended elsewhere [6].

\footnotetext{
Authors' details

'Obstetrics and Gynecology Department, King Abdulaziz University, Jeddah, Kingdom of Saudi Arabia. ${ }^{2}$ Center of Excellence in Genomic Medicine Research, King Abdulaziz University, Jeddah, Kingdom of Saudi Arabia. ${ }^{3}$ KACST Innovation Center for Personalized Medicine, King Abdulaziz University, Jeddah, Kingdom of Saudi Arabia.
}

Published: 2 April 2014

\section{References}

1. Munne S, Cohen J: Recurrent abortion and live birth rate per patient. Fertility and sterility 2006, 85(4):1071.

2. Seshadri S, Sunkara SK: Natural killer cells in female infertility and recurrent miscarriage: a systematic review and meta-analysis. Human reproduction update 2013, [Epub ahead of print].

3. Hodes-Wertz B, Grifo J, Ghadir S, Kaplan B, Laskin CA, Glassner M, Munne S: Idiopathic recurrent miscarriage is caused mostly by aneuploid embryos. Fertility and sterility 2012, 98(3):675-680.

4. McNamee K, Dawood F, Farquharson RG: Evaluation of array comparative genomic hybridization in recurrent miscarriage. $\mathrm{Br} J$ Hosp Med (Lond) 2013, 74(1):36-40.

5. Kochhar PK, Ghosh P: Reproductive outcome of couples with recurrent miscarriage and balanced chromosomal abnormalities. The journal of obstetrics and gynaecology research 2013, 39(1):113-120.

6. Munne S, Magli C, Bahce M, Fung J, Legator M, Morrison L, Cohert J, Gianaroli L: Preimplantation diagnosis of the aneuploidies most commonly found in spontaneous abortions and live births: $X Y, 13,14$, $15,16,18,21,22$. Prenatal diagnosis 1998, 18(13):1459-1466.
doi:10.1186/1471-2164-15-S2-P73

Cite this article as: Turki et al:: Analysis of chromosomal and genetic disorders in patients with recurrent miscarriages in Saudi Arabia. BMC Genomics 2014 15(Suppl 2):P73.

\section{Submit your next manuscript to BioMed Central and take full advantage of:}

- Convenient online submission

- Thorough peer review

- No space constraints or color figure charges

- Immediate publication on acceptance

- Inclusion in PubMed, CAS, Scopus and Google Scholar

- Research which is freely available for redistribution 